\title{
Prevalence of metallo- $\beta$-lactamase acquired genes among carbapenems susceptible and resistant Gram-negative clinical isolates using multiplex PCR, Khartoum hospitals, Khartoum Sudan
}

\author{
Mudathir Abdallah Adam* and Wafa I. Elhag*
}

\begin{abstract}
Background: The increased prevalence of carbapenem-resistant Gram-negative isolates caused by Metallo- $\beta$ lactamase (MBL) is worrisome in clinical settings worldwide. The mortality rate associated with infections caused by MBLs producing organisms ranging from 18 to $67 \%$.

This study aimed to determine the prevalence of Metallo- $\beta$-lactamase genes among some Gram-negative clinical isolates (Carbapenems susceptible and resistant).

Methods: This paper describes a descriptive cross-sectional study carried out to detect MBL genes such as (blaVIM, blaIMP and blaNDM) by multiplex PCR mixture reaction among $200 \mathrm{Gram}$-negative clinical isolates (Citrobacter spp, Escherichia coli, Enterobacter spp, Klebsiella pneumoniae, Pseudomonas aeruginosa, Proteus mirabilis, Proteus valgaris). Khartoum hospitals during 2015 to 2016.

Limitation: The study organisms were not evaluated for non-MBL carbapenemases, such as KPC and OXA-48.

Results: The prevalence of MBL genes by multiplex PCR assays among $200 \mathrm{Gram}$-negative clinical isolates was 72(36.1\%). MBL positive genes among 100 carbapenems sensitive and 100 resistant isolates were 27(27\%) and 45(45\%) respectively. There was a statistically, significant association between the antimicrobial susceptibility and the presences of MBL genes (P.value $=0.008$ ).

E.coli was the predominant species possessing MBL genes 26(36.1\%), with 22(30.7\%) species having a combination of MBL genes.

Verona integron Metallo beta-lactamase (VIM) was the most frequent genes 28(38.9\%) out of $72 \mathrm{MBL}$ detected genes, followed by imipenemase (IMP) was 19(26.4\%), and consequently, New Delhi Metallo beta lactamase was 3(4.2\%).

Conclusion: This study revealed a high prevalence of MBL genes in some Gram-negative isolates from Khartoum State Hospitals which were not previously established in these hospitals.
\end{abstract}

Keywords: Metallo $\beta$-lactamase, VIM, IMP, NDM, Carbapenem, PCR, Gram-negative bacteria, Khartoum

\footnotetext{
*Correspondence: mudathirdodo@gmail.com; Wafaelhag75@yahoo.com

Medical Microbiology Department, Faculty of Medical Laboratory Science, Al

Neelain University, Khartoum, Sudan
}

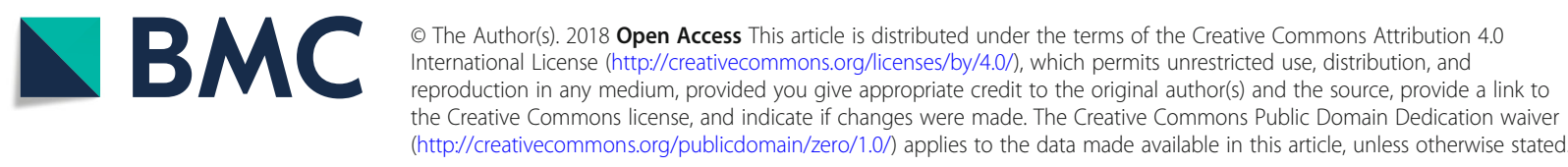




\section{Background}

The production of hydrolytic $\beta$-lactamase enzymes is the most prevalent resistance mechanism towards $\beta$-lactam antibiotics $[1,2]$. Metallo- $\beta$-lactamases constitute a worrisome group of enzymes, since they present a broad spectrum profile, hydrolyze penicillins, cephalosporins and carbapenems [1, 3], but not monobactams e.g.: aztreonam [4-7]. Carbapenem antibiotics are currently used as the last resort for treatment of the infections caused by multidrug-resistant Gram-negative bacteria [5, 7-9]. The mortality rate associated with MBL producers is reported to be from 18 to $67 \%[5,6]$.

The most prevalent families of MBL resistant genes worldwide are IMP (inactivate imipenem, first reported in Pseudomonas aeruginosa strain from Japan in 1988) [10]. While the VIM (Verona Integron-encoded Metallo$\beta$-lactamase) gene was first found in Europe, then emerged in other countries [7, 10]. However, NDM-producing bacteria were first isolated from a Swedish resident who contracted a urinary tract infection caused by carbapenem-resistant K.pneumoniae while he was in New Delhi in late 2007 [11-13]. Furthermore, the NDM gene later emerged in Pakistan, Indian subcontinent and the United Kingdom. Moreover, it represents a serious threat of rapid dissemination of multiple antibiotic resistance $[4,12,14]$.

Furthermore, the easy and rapid dissemination of acquired MBL within a bacterial species is a major issue regarding the treatment of individual patients and confronting infection policies [15].

In a study done in Khartoum, Sudan late 2012 by Abdelrazig and his colleague among 74 clinical isolates of Pseudomonas aeruginosa, 57 isolates were recognized to have IMP family genes (IMP-7 and IMP-10) using PCR assay [16].

Jamal W et al, (2013), reported in a study conducted in Mubarak Alkabeer hospital, Kuwait. There, out of 14 isolates of Enterobacteriaceae collected from intensive care units, eleven isolates produce VIM-4, and three isolates produced NDM-1 [17].

The study reported here aimed to detect (blaVIM, blaIMP and blaNDM) Metallo- $\beta$-lactamase genes in Khartoum state.

\section{Methods}

\section{Type and duration of the study}

This was a descriptive cross-sectional study, carried out during January 2015-December 2016 at different hospitals, Khartoum State.

\section{Samples}

A total of 200 samples of Gram-negative clinical isolates only susceptible and resistant to carbapenem antibiotics such as meropenem $10 \mu \mathrm{g}$ and imipenem $10 \mu \mathrm{g}$ were taken as part of the routine clinical procedure and stored for future analysis during six-month period from April 2015 to October 2015 from (Khartoum Teaching Hospital, Khartoum Pediatric Hospital, Omdurman Pediatric, El Blok Pediatric hospital, and Omdurman Medical Army Hospital) in Khartoum, Sudan. These strains were isolated from urine, wound swabs, sputum, blood, tissue aspirates, ear swab, and CSF samples.

Furthermore, the isolates were sub-cultured on cysteine electrolyte deficient (CLED) agar (HiMedia, India), and their identification was performed by biochemical tests such as oxidase test, Kligler iron agar (KIA), Indole test, citrate utilization, urease test and motility test.

\section{Antimicrobial susceptibility}

Susceptibility to antibiotics was determined by KirbyBauer disk diffusion on Mueller Hinton agar (HiMedia, India). Ordinarily, the tested isolates were picked up with a sterile wire loop and suspended in peptone water (Mast Group, UK). In a good light, the turbidity of the suspension was prepared equivalent to $0.5 \mathrm{McF}$ arland's standard. A plate of Mueller Hinton agar was inoculated with the suspension using a sterile cotton swab. The swab evenly over the surface of the medium was streaked and meropenem (MEM) $10 \mu \mathrm{g}$ and imipenem (IPM) $10 \mu \mathrm{g}$ antimicrobial discs were placed. The plate was incubated aerobically at $35^{\circ} \mathrm{C}$ for overnight $[18,19]$. The inhibition zone diameters were measured by $(\mathrm{mm})$ according to Clinical and Laboratory Standards Institute (CLSI) guidelines (2011) [19].

Thus, in this study carbapenem resistance was defined as testing non -susceptible to either meropenem and/ or imipenem. However, carbapenem susceptibility was defined as testing susceptible either to meropenem and/ or imipenem. Two strains were detected as intermediate and they considered resistant because the value of intermediate breakpoint was closer to the breakpoint of resistant.

\section{Multiplex PCR}

MBL genes including (blaVIM, blaIMP and blaNDM) were screened among all isolates by multiplex polymerase chain reaction (PCR). Consequently, total DNA targeting both genomic and plasmid DNA was extracted with chloroform/ isopropanol chemical method. Specific primer for target DNA (MBL genes) designed by (Metabion/ Germany).

IMP-F: (5'GGA ATA GAG TGG CTT AAC TCT C 3') and IMP-R: (5' CGA ATG CGC ACC AG 3') 232 bp.

VIM-F: (5' TGG TGT TTG GTC GCA AT 3') and VIM-R: (5'CGA ATG CGC ACC AG 3') 390 bp.

NDM-F: (5' CGG AAT GGC TCA TCA CGA TC 3') and NDM-R: (5' GGT TTG GCG ATC TGG TTT TC 3) $621 \mathrm{bp}$. 
Table 1 Distribution of clinical bacterial isolates $(n=200)$ according to their carbapenems susceptibility

\begin{tabular}{llll}
\hline Organisms & Sensitive No (\%) & Resistant No (\%) & Total No (\%) \\
\hline E.coli & $45(22.5)$ & $26(13)$ & $71(35.5)$ \\
P.aeruginosa & $21(10.5)$ & $33(16.5)$ & $54(27)$ \\
K.pneumoniae & $21(10.5)$ & $29(14.5)$ & $50(25)$ \\
P.mirabilis & $12(6)$ & $9(4.5)$ & $21(10.5)$ \\
P.valgaris & - & $2(1)$ & $2(1.0)$ \\
Enterobacter spp & - & $1(0.5)$ & $1(0.5)$ \\
Citrobacter spp & $1(0.5)$ & - & $1(0.5)$ \\
Total No (\%) & $100(50)$ & $100(50)$ & $200(100)$ \\
\hline
\end{tabular}

Every organism of the study population was tested with the three different primers in a single test.

Multiplex PCR amplifications were carried out in 20- $\mu$ l

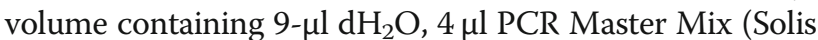
BioDyne, Estonia) ready to load, $3 \mu \mathrm{l}$ of the three primer mixtures and 4- $\mu$ DNA template. The PCR amplifications were performed by thermo-cycler machine (TC-412, UK), using the following cycling parameters: one cycle (initial denaturation) $2 \mathrm{~min}$ at $95^{\circ} \mathrm{C}, 30$ cycles (denaturation) 30 Sec at $95^{\circ} \mathrm{C}, 30$ cycles (annealing) $30 \mathrm{Sec}$ at $48^{\circ} \mathrm{C}, 30$ cycle (elongation) $30 \mathrm{Sec}$ at $72^{\circ} \mathrm{C}$, and $2 \mathrm{~min}$ (final extension) at $72^{\circ} \mathrm{C}$. Moreover, the PCR product was resolved using $1.5 \%$ agarose gel electrophoresis to detect specific amplified product by comparing with standard molecular weight marker 50 base pairs (DNA ladder).

Limitation: The study organisms were not evaluated for non-MBL carbapenemases, such as KPC and OXA-48.

Data (Additional file 1) were analyzed by the Statistical package of social sciences (SPSS) programmed for Windows, version 16.

\section{Results}

Different bacterial species were studied. Most were E.coli 71(35.5\%) followed by Pseudomonas aeruginosa 54(27\%), and less predominant organisms were Citrobacter spp and Enterobacter spp 1(0.5\%) each, (Table 1).

The overall results revealed that $72(36.1 \%)$ from 200 clinical Gram-negative isolates, were positive for one or a combination of MBL genes. Consequently, MBL positive genes among 100 carbapenems sensitive and 100 resistant isolates were $27(27 \%)$ and $45(45 \%)$ respectively, the analysis showed statistically significant $($ P.value $=0.008)$ between carbapenem susceptibility and MBL genes (Table 2).

The MBL genes were heterogeneously distributed among the different species of Gram-negative isolates, with 22(30.7\%) species having a combination of MBL genes. Moreover, E.coli was the predominant species possessing MBL genes 26(36.1\%) (Table 3).

Verona integron Metallo beta-lactamase (VIM) was the most frequent gene detected in $28(38.9 \%)$ out of 72 positive MBLs genes, then, imipenemase (IMP) detected in $19(26.4 \%)$, and $N D M$ reported in 3(1.5\%) (Table 4).

Three possible Metallo $\beta$-lactamase (MBL) resistant genes (blaVIM, blaIMP and blaNDM), which detected in this study using PCR were illustrated on an agarose gel according to their amplicon size (Fig. 1).

\section{Discussion}

Metallo- $\beta$-lactamase has emerged as a powerful resistance determinant in Gram-negative bacteria [20, 21], causing health problems of global dimensions [22-25] which can threatens human being with their newly built genetic structure [21], and play a principal role in drug resistance [22, 26, 27].

In general data on the dissemination of antimicrobial genes on sub-Saharan Africa is scarce, especially regarding the prevalence of MBL genes [28]. To our knowledge, this is not the first report of the presence of MBL encoding genes in Khartoum state, Sudan, a number of studies have been carried out, including a detection of IPM types in Pseudomonas aeruginosa performed by Abdelrazig and her colleague [16], NDM mediated carbapenem resistance was recently described by Mohamed et al. [29]. In addition to (TEM, VIM, IMP, SHV, CTX, and $K P C$ ) antimicrobial resistance genes among Gram-negative isolates were determined by Satir et al. [30]. By contrast, there are no published data regarding (IPM, VIM and NDM) carrying bacteria have been described in other regions of Sudan.

We believe this study represents the first report of the prevalence of (IPM, VIM and NDM) MBL encoding genes among Gram-negative isolates in Khartoum State, Sudan.

Furthermore, reports of emerging (IPM, VIM and $N D M)$ MBL genes among Gram-negative strains have been published worldwide, including sub-Saharan Africa and Middle East countries such as Ethiopia [28], Kenya

Table 2 Frequency rate of MBLs genes among Carbapenems sensitive and resistant Gram-negative isolates

\begin{tabular}{llll}
\hline Organisms & Positive MBLs genes No (\%) & Negative MBLs genes No (\%) & Total No (\%) \\
\hline Carbapenems resistant & $45(22.5)$ & $55(27.5)$ & $100(50)$ \\
Carbapenems sensitive & $27(13.5)$ & $73(36.5)$ & $100(50)$ \\
Total & $72(36)$ & $128(64)$ & $200(100)$ \\
\hline
\end{tabular}

P.value $=0.008$ 
Table 3 Frequency rate of distribution of MBLs genes among the species of Gram-negative isolates

\begin{tabular}{|c|c|c|c|c|c|c|}
\hline \multirow[t]{2}{*}{ MBLs genes } & \multicolumn{5}{|l|}{ Organisms } & \multirow{2}{*}{$\begin{array}{l}\text { Total } \\
\text { No (\%) }\end{array}$} \\
\hline & K.pneumoniae No (\%) & E.coli No (\%) & P.aeruginosa No (\%) & P.mirabilis No (\%) & P.valgaris No (\%) & \\
\hline VIM & $7(9.7)$ & $12(16.7)$ & $8(11.1)$ & $1(1.4)$ & $0(0)$ & $28(38.9)$ \\
\hline IMP & $8(11.1)$ & $6(8.3)$ & $4(5.6)$ & $1(1.4)$ & $0(0)$ & $19(26.4)$ \\
\hline NDM & $0(0)$ & $2(2.8)$ & $1(1.4)$ & $0(0)$ & $0(0)$ & $3(4.2)$ \\
\hline VIM\&IMP & $0(0)$ & $2(2.8)$ & $1(1.4)$ & $0(0)$ & $0(0)$ & $3(4.2)$ \\
\hline VIM\&NDM & $3(4.2)$ & $2(2.8)$ & $6(8.3)$ & $0(0)$ & $0(0)$ & $11(15.3)$ \\
\hline IMP\&NDM & $1(1.4)$ & $1(1.4)$ & $2(2.8)$ & $0(0)$ & $0(0)$ & $4(5.6)$ \\
\hline VIM\&IMP\&NDM & $1(1.4)$ & $1(1.4)$ & $1(1.4)$ & $0(0)$ & $1(1.4)$ & $4(5.6)$ \\
\hline Total & $20(27.8)$ & $26(36.1)$ & $23(31.9)$ & $2(2.8)$ & $1(1.4)$ & $72(100)$ \\
\hline
\end{tabular}

Key: VIM: Verona integron metallo- $\beta$-lactamase. IMP: Imipenemase. NDM: New Delhi metallo- $\beta$-lactamase

[11], Uganda [31], Egypt [32], South Africa [33], Saudi Arabia [2], Iraqi [4], Kuwait [17], and Lebanon [34].

MBL genes prevalence among carbapenem-resistant isolates was found $45(45 \%)$ out of 100 , which agrees with MBL genes prevalence from Tanzania, Romania, India and Egypt by Mushi [5], Mereuță et al, [35], Amudhan et al, [36], and Nelly, et al., [37], they reported $42 \%$, $46(43.4 \%), 92(51.4 \%)$ and $12(52.2 \%)$ respectively. This is a worrying result, probably due to the unjudged antibiotics use patterns in these countries.

However, our results were higher than studies conducted in Malaysia, Egypt, Uganda and Iraq by Khosravil [38] Zafer et al, [31], Okoche [39], and Anoar et al [4], they found $36,31.3,28.6 \%$, and $39(22 \%)$ the prevalence of MBL genes respectively.

MBL genes prevalence among carbapenem sensitive isolates were found $27(27 \%)$ out of 100 , this finding was higher than that found by Anoar et al, in Iraq, 7(3.9\%) [4], ordinarily, MBL genes presence among carbapenems sensitive strains indicate that there might be a hidden MBL genes not detected by phenotypic tests, leading to the silent spread of these genes in the hospitals and the community.

Table 4 Frequency rate of MBL genes among the sensitive and resistant Gram-negative isolates

\begin{tabular}{llll}
\hline MBLs genes & \multicolumn{2}{l}{ Gram-negative isolates } & \multicolumn{1}{l}{$\begin{array}{l}\text { Total } \\
\text { No }\end{array}$} \\
\cline { 2 - 3 } & Sensitive No (\%) & Resistant No (\%) & \\
\hline VIM & $12(16.7)$ & $16(22.2)$ & $28(38.9)$ \\
IMP & $12(16.7)$ & $7(9.7)$ & $19(26.4)$ \\
NDM & $0(0)$ & $3(4.2)$ & $3(4.2)$ \\
VIM\&IMP & $1(1.4)$ & $2(2.8)$ & $3(4.2)$ \\
VIM\&NDM & $1(1.4)$ & $10(13.9)$ & $11(15.3)$ \\
IMP\&NDM & $1(1.4)$ & $3(4.2)$ & $4(5.6)$ \\
VIM\&IMP\&NDM & $0(0)$ & $4(5.6)$ & $4(5.6)$ \\
Total & $27(37.5)$ & $45(62.5)$ & $72(100)$ \\
\hline
\end{tabular}

This study revealed that MBL genes prevalence among carbapenem-resistant and sensitive isolates was (36.1\%), which was agreed to that reported in Iraq, and Iran by, Anoar et al, [4], Aghamiri et al, [40] were 46(25,9\%), and 90(42\%), respectively. The difference may be due to the variation of geographical circulating strains.

Verona integron Metallo-beta-lactamase (VIM) was the most frequent gene represent 28 (38.9\%) among 72 positive MBL genes, imipenemase (IMP) represent 19 (26.4\%), and the NDM was the least detected in 3(1.5\%).

Our results agree with studies done in Uganda, Tanzania, Egypt and Iran by Okoche et al, [39] Mushi [5], Zaferet al, [31] and Aghamiri [40], they reported the frequencies of (VIM, IMP and NDM) as: [21(10.7\%), $12(6.1 \%)$ and 5(2.6\%)], [34(15\%), 28(12\%), and 9(4\%)], [58.3, 4.2 and $2.1 \%]$ and $[70(33 \%)$ and $20(9 \%)]$ respectively. However, our findings were disagrees with that found in Iraq by Anoar et al, ${ }^{(4)}$ they reported IMP was the most frequently detected gene 33(18.6\%), VIM 19(10.7\%), and NDM 2(1.12\%) isolates.

E.coli was the most isolate harbours MBL genes 26(36.1\%), followed by Pseudomonas aeruginosa 23(31.9\%). Moreover, 22 isolates have harboured a combination of MBL genes. These findings disagree with Okoche et al, study, where K.pneumoniae was the most frequent MBL genes harbour 35(52.2\%), and then 19(28.4\%) E.coli, and 8 isolates of MBL genes positive harboured a combination of MBL genes similar to our findings [39].

\section{Conclusions}

This study revealed a high prevalence of MBL genes in some Gram-negative isolates from Khartoum State Hospitals, all the three genes assayed (blaVIM, blaIMP and blaNDM) were detected in the study samples.

Detection of MBL genes among isolates which reported as sensitive to carbapenem was acting as a reservoir of 


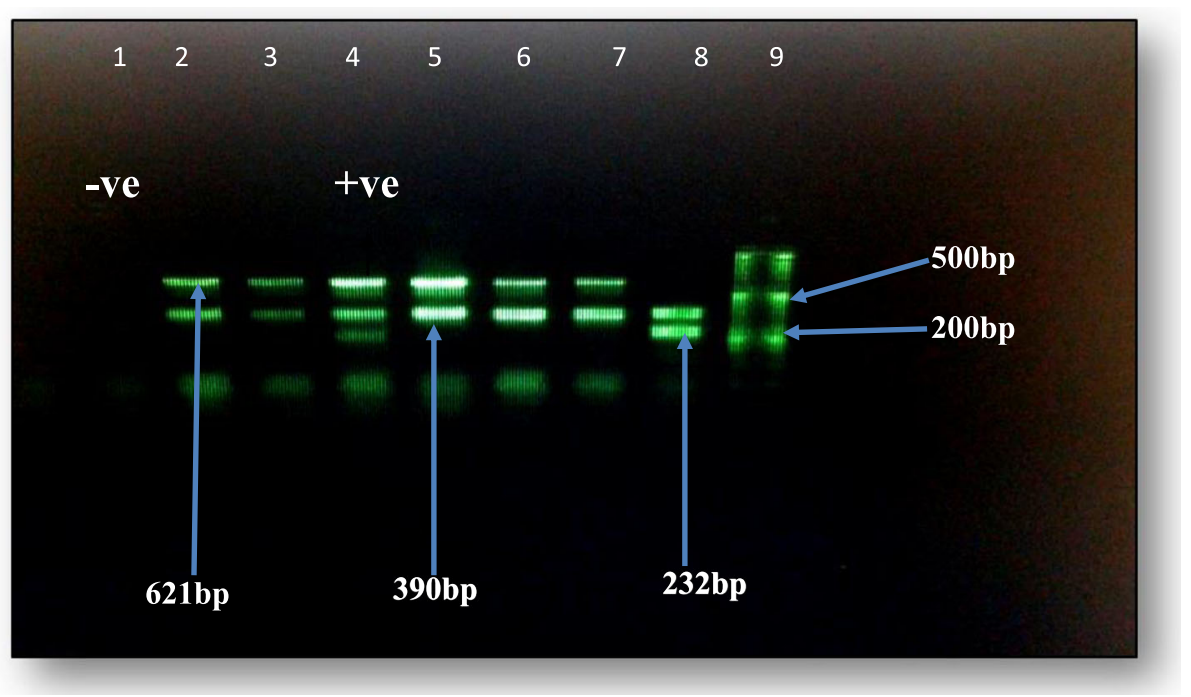

Fig. 1 PCR product on Gel electrophoresis for MBLs genes among Gram-negative bacteria. Key. Lane 1: -ve control lanes 2, 3, 5, 6\&7: 390 bp bla-vim \& 621 bp bla-nDM, and lane 4: (+ve control) 232 bp bla-IMp, 390 bp bla-vIm \& 621 bp bla-nDM. Lane 8: 232 bp bla-ımp\& 390 bp bla-vim, Lane 9: DNA ladder $50 \mathrm{bp}$

such resistance genes with potential risk for the silent spread of these genes in hospitals and community.

This is the first report of the prevalence of (VIM, IMP and $N D M$ ) MBL genes in Gram-negative strains in Khartoum State, Sudan.

We recommend a regular screening and monitoring system should be set up to prevent the dissemination of these genes in the country.

\section{Additional file}

Additional file 1: Samples, strains, PCR result information. (XLSX $18 \mathrm{~kb})$

\section{Abbreviations}

bla: Beta-lactamase; CLED: Cysteine electrolytes deficient medium; CLSI: Clinical laboratory standard institute; CTX: Cefotaximase; DNA: Deoxyribonucleic acid; IMP: Imipenemase; KPC: Klebsiella pneumonia carbapenemases; MBL: Metallo- $\beta$-lactamase; NDM: New Delhi Metallo- $\beta$ lactamase; OXA-48: Oxacillinase-48; PCR: Polymerase chain reaction; SHV: Sulfhydryl variable; TC: Thermal cycler; TEM: Temoneira; UK: United Kingdom; VIM: Verona Metallo-ß-lactamase

\section{Acknowledgements}

We do acknowledge the efforts of Mr. Mohammed Alfatih, Miss. Hadeel Ismail and Miss. Nafisa Ahmed (research laboratory and medical laboratory department, Faculty of Medical Laboratory Sciences, Al Neelain University) for their technical support.

\section{Funding}

The study was supported partially by the Faculty of Medical Laboratory Sciences, Al Neelain University, Sudan. Funding body has no role in the design of the study, collection, analysis, and interpretation of data and writing the manuscript.

\section{Availability of data and materials}

The data analyzed during the current study are presented within an additional spreadsheet file.

\section{Authors' contribution}

MAA, designed, conducted the study and drafted the paper. WIE coordinated the laboratory quality control, revised and approved the manuscript critically for important intellectual contents. All authors read and approved the final manuscript.

\section{Ethics approval and consent to participate}

Not applicable.

The study was based on laboratory work performed with bacterial strains isolated from patient's samples during regular hospitals work up. Ethical clearance is not required for the work with isolated bacteria in Al Neelain University.

\section{Consent for publication}

Not applicable.

\section{Competing interests}

The authors declare that they have no competing interests.

\section{Publisher's Note}

Springer Nature remains neutral with regard to jurisdictional claims in published maps and institutional affiliations.

Received: 9 February 2018 Accepted: 3 December 2018

Published online: 17 December 2018

\section{References}

1. Meini MR, Llarrull LI, Vila AJ. Evolution of Metallo- $\beta$-lactamases: trends revealed by natural diversity and in vitro evolution. Antibiotics. 2014;3: 285-316.

2. Shaik S, Fatima J, Shakill S, Rizvi SMD. Antibiotic resistance and extendedspectrum beta-lactamases: types, epidemiology, and treatment. Saudi Biol Sci. 2015;22(1):90-101.

3. Worthington RJ, Melaner C. Overcoming resistance to $\beta$-lactam antibiotics. J Org Chem. 2013;78(9):4207-13.

4. Anoar KA, Ali FA, Omer SA. Detection of Metallo $\beta$-lactamase enzyme in some gram-negative bacteria isolated from burn patients in Sulaimani city, Iraq. European Scientific J. 2014;10(1):485-96.

5. Mushi MF. Carbapenems-resistance determining genes among multidrug resistance gram-negative bacterial clinical isolates, in Tanzania (Master's thesis) (internet) University of Makerere; 2013. 
6. Rawat $\mathrm{V}$, Singhai $M$, Verma PK. Detection of different $\beta$-lactamases and their co-existence by using various discs combination methods in clinical isolates of Enterobacteriaceae and Pseudomonas spp. J Lab Physicians. 2013;5:21-5.

7. Pitout JDD, Chow BL, Gregson DB, Laupland KB, Elsayed S, Church DL. Molecular epidemiology of Metallo- $\beta$-lactamase-producing Pseudomonas aeruginosin the Calgary health region: emergence of VIM-2-producing isolates. J Clin Microbiol. 2007:45(2):294-8.

8. Bennett PM. Plasmid-encoded antibiotic resistance genes in bacteria. Br J Pharmacol. 2008;153(suppl 1):S347-57.

9. Papp-Wallace KM, Endimiani A, Taracila MA, Bonomo RA. Carbapenems: past, present, and future. Antimicrob Agents Chemother. 2011;55(11):4943-60.

10. Peymani A, Farivar TN, Ghanbarlou MM, Najafipour R. Dissemination of PS. aeruginosa producing blalMP-1 and blaVIM-1 in Qazvin and Alborz educational hospital, Iran. Iran J Microbiol. 2015;7(6):302-9.

11. Poirel L, Revathi G, Bernabeu S, Nordmann P. Detection of NDM-1producing Klebsiella pneumoniae in Kenya. Antimicrob Agents Chemother. 2011;55(2):934-6.

12. Thoms-Rodriguez C, Mazzulli T, Christian N, Willey BM, Boyed DA, Mataseje LF, et al. New Delhi Metallo- $\beta$-lactamase in Jamaica. J Infect Dev Ctries. 2016;10(2):183-7.

13. Warnes SL, Highmore CJ, Keevil CW. Horizontal transfer of antibiotics resistance genes on abiotic touch surfaces: implications for public health. MBio. 2012;3(6):e00489-12.

14. Martin K, Florian S, Lars W, Gaterman G. Detection of Carbapenemases in Enterobacteriaceae by commercial multiplex PCR. J Clin Microbiol. 2012;50(9): 3115-8.

15. Borra NS. Structural and biochemical investigation of Metallo-ß-lactamases Insights into the antibiotic binding sites, in northern Norway (Ph.D. Thesis) (internet) University of Tromso; 2012.

16. Abdelrazig MD, HamedEInil YF. Molecular characterization and sensitivity pattern of Pseudomonas aeruginosa among patients with different diseases in Khartoum, Sudan. J Sci Technol. 2012;13(12):32-6.

17. Jamal W, Rotimi VO, Albert MJ, Khodakhast F, Nordmann P, Poirel L. High prevalence of VIM-4 and NDM-1 Metallo-beta-lactamase among carbapenemresistant Enterobacteriaceae. J Med Microbiol. 2013;62(8):1239-44.

18. Cheesbrough M. Antimicrobial susceptibility testing. In: Distinct laboratory practice in tropical countries part 2, 2nd ed. New York: Cambridge University Press, 2006, ch 7. Pp 135-141.

19. CLSI. Performance Standards for Antimicrobial Susceptibility Testing; Twenty-First Informational Supplement. CLSI document M100-S21. Wayne: Clinical and Laboratory Standards Institute; 2011. p. 42-63.

20. Logan LK, Bonomo RA. Metallo-beta-lactamase (MBL)-Producing Enterobacteriaceae in United States Children. Open Forum Infect Dis. 2016; 3(2):ofw090.

21. Padhi S. New Delhi Metallo-beta-lactamase: a weapon for the newly emerging drug-resistant bacteria. Indian J Med Sci. 2011;65(8):317-20.

22. Hammood HN. The emergence of NDM-1 among carbapenems-resistance in Iraqi hospitals. Acta Microbiol Immunol Hung. 2017;9:1-17.

23. Maltezou HC. Metallo- $\beta$-lactamases in gram-negative bacteria: introducing the era of pan-resistance. Int J Antimic Agent. 2009;33(5):405.e1-7.

24. Thapa P, Bhandari D, Shrestha D, Parajuli H, Chaudhary P, Amatya J, et al. A hospital-based surveillance of Metallo-beta-lactamase-producing gramnegative bacteria in Nepal by imipenem-EDTA disk method. BMC Research Notes. 2017;10:322

25. Nordman P, Carrer A. Carbapenemases in Enterobacteriaceae. Arch Pediatr. 2010;17(suppl 4):S145-62.

26. Rahal J. The role of carbapenems in initial therapy of serious gram-negative infections. Crit Care. 2008;12(suppl 4):55.

27. Safari M, Nejad ASM, Bador A, Jafari R, Khani MYA. Prevalence in Acinetobacter baumannii strains isolated from patients of intensive care units (ICU). Saudi J Biol Sci. 2015;22(4):424-9.

28. Pritsch M, Zeynudin A, Messerer M, Baumer S, Liegl G, Schubert S, et al. First report on blanDM-1-producing Acinetobacter baummanii in three clinical isolates from Ethiopia. BMC Infect Dis. 2017;17:180.

29. Mohamed SGR, Alobied A, Saeed MI, Hussien WM. New Delhi Metallo- $\beta$ lactamase (NDM)-mediated Carbapenem-resistant Pseudomonas aeruginosa clinical isolate in Sudan. SAJRM. 2018;1(3):1-5.

30. Satir S, Elkalifa MA, Ali MA, El Hussein AM, Elkhidir IM, Enan KA. Detection of Carbapenem-resistant genes among selected gram negative bacteria isolated from patients in-Khartoum state, Sudan. Clin Microbiol. 2016:5:6.
31. Zafer MM, Al-Agamy NH, El-Mahallawy HA, Amin MA, Ashour MS Antimicrobial resistance pattern and their $\beta$-lactamase encoding genes among Pseudomonas aeruginosa strains isolated from cancer patients. Bio Med Research Int. 2014;e101635:2014

32. Diab M, Fan N, El-Said M, El-Dabaa E, El-Defrawy I, Saber M. Occurrence of VIM-2 Metallo- $\beta$-lactamases in imipenem resistant and susceptible Pseudomonas aeruginosa clinical isolates from Egypt. Afri J Microbiol. 2013; 7(35):4465-72.

33. Sigh-Moodley A, Perovic O. Antimicrobial susceptibility testing in predicting the presence of carbapenemase genes in Enterobacteriaceae in South Africa. BMC Infect Dis. 2016:16:536.

34. El-Herte Rl, Araj GF, Mata GM, Baroud M, Kanafani ZA, Kanj SS. Detection of carbapenem-resistant Escherichia coli and Klebsiella pneumonia producing NDM-1 in Lebanon. J Infect Dev Ctries. 2012;6(5):451-61.

35. Mereută Al, Bădescu AC, Dorneanu OS, lancu LS, Tuchiluş CG. Spread of VIM-2 metallo-beta-lactamase in Pseudomonas aeruginosa and Acinetobacter baumannii clinical isolatesfrom lasi, Romania. Revista Românăde Medicinăde Laborator. 2013;21(12):423-30.

36. Amudhan MS, Sekar U, Kamalanathan A, Balaraman S. Bla-ımp and Bla-viM mediated carpabenem resistance in Pseudomonas and Acinetobacer species in India. J Infect Dev Ctries. 2012;6(11):757-62.

37. Nelly M, Raafat M, Raafat D. Phenotypic and genotypic detection of MBLs in imipenem-resistance A.baumanii isolates from a tertiary hospital in Alexandria, Egypt. Egypt Res J Microbiol. 2011;6(10):750-60.

38. Khosravi Y, Vellasamy KM, Tay ST, and Vadivelu J. Molecular detection and characterization of Metallo- $\beta$-lactamase (MBL) genes and integrons of imipenem -resistant Pseudomonas aeruginosa. A. Méndez-Vilas, Ed: (2013); 515-521.

39. Okoche D, Asiimwe BB, Katabazi FA, Kato L, Najjuka CF. Prevalence and characterization of Carbapenem-resistant Enterobacteriaceae isolated from Mulago National Referral Hospital, Uganda. PLoS One. 2015;10(8): e0135745. https://doi.org/10.1371/journal.pone.0135745.

40. Aghamiri S, Amirmozafari N, FallahMehrabadi J, Fouladtan B, Samadi KH. Antibiotic resistance pattern and evaluation of Metallo-Beta lactamase genes including Bla-ımp and Bla-vim types in Pseudomonas aeruginosa isolated from patients in Tehran hospitals. ISRN Microbiol. 2014;2014:941507.

\section{Ready to submit your research? Choose BMC and benefit from:}

- fast, convenient online submission

- thorough peer review by experienced researchers in your field

- rapid publication on acceptance

- support for research data, including large and complex data types

- gold Open Access which fosters wider collaboration and increased citations

- maximum visibility for your research: over $100 \mathrm{M}$ website views per year

At BMC, research is always in progress.

Learn more biomedcentral.com/submissions 